Modeling in branding: A critical ethnography approach

Authors: Ayman El-Amir* and Steve Burt**

(*) Ayman El-Amir (Corresponding Author)

Assistant Professor, Business Administration Program

Trent University, Peterborough K9J 7B8, Ontario,

Canada

Email: aymanelamir@trentu.ca

Tel: +1(705)7481011-ext.7106

$(* *)$ Steve Burt

Professor of Retail Marketing

Institute for Retail Studies, Stirling Management School

University of Stirling, Stirling FK9 4LA, Scotland, UK

Email: s.l.burt@stir.ac.uk

Tel: + 44(0)1786 467399 


\title{
Modeling in branding: A critical ethnography approach
}

\begin{abstract}
Purpose- The paper aims to shed light on the potential of ethnography to provide a dialectical approach to modeling the process of branding as its focus widens from managerial to social.
\end{abstract}

Design/methodology/approach- A critical approach to ethnography is adopted and implemented in light of the French sociologist Pierre Bourdieu's ethnographic modeling technique of ‘Participant Objectification’ (Bourdieu and Wacquant, 1992).

Findings-The paper demonstrates from the customer standpoint- of a case of a grocery retailer- the ability of critical ethnography to dialectically model the branding process as an organic cultural whole, which envelops an intricate set of different, yet interdependent, social and managerial systems, functioning in a coherent and complementary manner.

Research limitations- The empirical evidence is limited to the area of grocery retailing. Thus, widening the application of the technique in other areas would be desirable.

Practical implications- The dialectical nature of the critical approach to modeling yields a rich multi-faceted view of the branding process that could help remedy the problem of detachment from complex reality, which has often been a criticism of traditional approaches to modeling in marketing.

Originality/Value- The suggested dialectical approach to modeling expands the potential use of ethnography within the critical orientation to theory building in marketing generally, and branding in particular through elaborating the process of cultural construction from textual via participant observation to dialectical via participant objectification.

Key words Branding, Critical marketing, Ethnographic modeling, Market research

Paper type Research paper

\section{Introduction}

Modeling in marketing and brand management is grounded in the three approaches to theory development commonly found in management research: the 'positivist' (thesis); the 'relativist' (anti-thesis) and the 'critical' (synthesis) (Johnson and Duberley, 2003 p.1282). The former is, however, the dominant approach in marketing (Malhotra et al. 
1999; Leeflang and Wittink, 2000; Burton, 2005). For many, such an obsession with (thesis-testing) positivism is dragging theory construction (thesis-building) in marketing down, creating self-imposed isolation from its open/multidisciplinary theoretical and practical base (Leeflang and Wittink, 2000; Burton, 2002, 2005; Brownlie, 2006). Similarly, although valuable in its ability to provide a continuous critique to positivism (Brown, 1993), the relativist approach has largely proved elusive and ultimately selfdefeating as a means for theorizing in marketing (Kent, 1996). As a result, the critical approach, a rapidly growing stance in marketing (Saren et al. 2007), is felt to have the greatest potential to offer a continuous critique of existing marketing knowledge grounded in actual practices and inspired by a multi-disciplinary orientation - and to construct the more macro and inclusive views that constantly develop marketing theory (Burton, 2005; Brownlie, 2006). Furthermore, befitting the empirically grounded and multi-disciplinary nature of critical theorizing, the ability of ethnographic inquiry to empirically link the 'part to the whole' has proved central to critical theory construction (Thomas, 1983; Baszanger and Dodier, 1997 (p.8); Kincheloe and McLaren, 2000).

As research in marketing has broadened its focus from a strictly managerial to a multidisciplinary social orientation (Calonius, 2006), research in branding has also moved from a managerial (closed) approach to a social (open/ multi-disciplinary) one (Pitt et al., 2006). The purpose of this paper is to argue that the ability of ethnography to critically construct theory provides brand management research with an appropriate approach to empirically model branding as a social process. 
To fulfill this aim, the paper will first review the role of ethnography in marketing and branding research, to shed light on the increasing need to model brands as social processes. Second, the role of critical ethnography in modeling social processes is discussed in light of the French sociologist Pierre Bourdieu's Participant Objectification technique. Third, the potential of critical ethnography in modeling branding as a social process will be demonstrated through a case study which sought to socially construct the grocery retailer as a brand from a customer standpoint. The paper will conclude with a discussion of the potential to model brands critically.

\section{The role of ethnography in marketing and branding research}

In managerial research, ethnography has proved to be the most effective method to unravel organizational reality (Mintzberg, 1979; Gummesson, 2000). Following this lead, 'ethnographies of marketing', as the understanding of how the systems of managing marketing activities in organizations work, came to the fore (Arnould and Wallendorf, 1994 (p.484). However, ethnographies of marketing have been criticized for their narrow perspective - focusing on organizing in marketing and missing the wider social context of which marketing is an integral part (Brownlie, 1997). Thus, Arnould and Wallendorf (1994:484) argued that ethnography in marketing should shift from a managerial to a market orientation that, in turn, studies the interplay between marketing management and society (those who consume) in 'market-oriented ethnographies'. Market-oriented ethnographies adopt a balanced approach which is crucial to deciphering the social consumption of the strategic marketing activities of organizations by its customers (Arnould and Wallendorf, 1994; Elliott and Jankel-Elliott, 2003). 
Following calls to broaden branding from a managerially closed to a socially open process (Pitt et al., 2006), research in branding has also started to drift away from the narrow scientific (managerial) approach to embrace a broad ethnographic (social) one which is capable of depicting the branding process in a more holistic (open) manner. The classic managerial approach of brand equity research is primarily concerned with exerting control over the branding process in order to maximize profits (Kapferer, 1997; Keller, 2008). Conceptualisations of brand equity envisage branding as a firm-led structured process through which customers give systematically measurable feedback (Dyson et al., 1996; Keller, 2008). This view is reflected in the tendency within brand equity research to geometrically model the branding process through circles, diamonds, triangles (see Gordon (1999) for a comprehensive review), and most prominently pyramids (Dyson et al., 1996; Keller, 2008). This stance has been criticized for providing a rigid scientific view of brands (Holt, 2002).

In contrast, the brand identity approach offers a more flexible social view that engages the customer with the brand at the personality level (Aaker, 1996; Kapferer, 1997). In this case, branding is conceptualized as a process creating psychological congruence between customer and brand personalities primarily through the brand's integrated marketing communications. As a result, brand identity research generates strategic communication models that capture the structure of the brand-customer dialogue as depicted in Kapferer's (1997) brand identity prism, de Chernatony and Riley’s (1998) rotating double-vortex model, and the flow-charts of Aaker (1996). Within this stream of 
research, 'micro- ethnographic' studies were adopted to objectively describe the strategic dialogue between a brand and its customers (e.g. product ease of use, customer interpretation of advertising, etc.) (Elliott and Jankel-Elliott, 2003; Arnould and Price, 2006 p.253). However, as it is argued that personality is only the tip of the iceberg of social behavior (Reed, 2002), Holt (2002) has criticized this approach as shallow and essentially promotional.

The anthropological view of brands, where the value of a brand lies in its ability to convey a bundle of meanings rooted in the culture (McCracken, 1993), marked a further shift in the branding process - towards a deeper social orientation where culture takes centre stage. In this approach, the role of ethnography moved from a narrow objective/descriptive orientation (micro-ethnography) to a holistic interpretive orientation typified as a 'textual construction' of culture (Moisander and Valtonen, 2006 p.55) and labeled as 'macro-ethnography' (Arnould and Price, 2006 p.252). These textual ethnographic constructions aim to depict the cultural meanings through which customers bond with specific brands in sub-cultures/communities of consumption (Muniz and O’Guinn, 2001; Elliott and Jankel-Elliott, 2003), for example the ethnographies of freedom in the Harley-Davidson biker community (Schouten and McAlexander, 1995) and of authenticity within the community of MG car owners (Leigh et al., 2006).

In a postmodern society, however, this approach generated some concerns about the commercialization of culture via brands (Klein, 2000; Holt, 2002; Arvidsson, 2005). The recognition of post-postmodern consumers who tend to use (rather than rely on) 
brands to construct their own social self-meaning (identity) (Holt, 2002) led to the rise of the cultural approach to branding as a sociological process of meaning co-construction between customers and brands (Holt, 2004). In response to this shift in approach, the textual construction of ethnography itself switched focus from understanding customers as active brand meaning consumers (as in the anthropological approach to branding) to active producers of brand meaning. Arnould and Price (2006 p.252) have labeled this as 'meso-ethnography', typified by ethnographies of family identity construction via homemade food (Moisio et al., 2004) and the role of habitual/everyday brands in people’s lives (Coupland, 2005).

As demonstrated above, market-oriented ethnography has become more and more central to understanding the branding process as it gradually moves from a managerial construct to a cultural construct. Accordingly, calls for qualitative approaches to modeling in marketing have been raised, as the traditional quantitative approaches are struggling to adjust to this changed emphasis (Ehernberg et al., 2000; Leeflang and Wittink, 2000, Roberts, 2000). To illustrate, the modeling of consumer behaviour in marketing has traditionally been heavily associated with mathematical constructs to achieve precise measurements (Moorthy, 1993; Dupe et al. 2005). The use of such constructs in itself has, however, posed limitations on the degree of precision gained from these models, as understanding highly dynamic consumer behavior is mathematically infeasible (Moorthy, 1993). Models constructed in this manner are unable to account for actual behavior, and hence resort to mathematically feasible techniques to make inferences (see Dupe et al. 2005). In other words, one could argue that conventional mathematical modeling is 
forcing consumption to fit the laws of mathematics rather than the reverse. This paper argues that there is a qualitative alternative to the traditional quantitative approaches to modeling consumer behavior, which is encapsulated in the critical approach to ethnography.

The ethnographic approach can provide feasible and precise understandings of consumer behavior that allow the modeling of the process of branding as it is socially constructed by consumers. The French sociologist Pierre Bourdieu was a pioneer in applied critical ethnography (Kincheloe and McLaren, 2000). His theory of cultural capital- culture is historically re/produced by its social agents in their everyday lives (Bourdieu, 1979)- has been acknowledged as the most comprehensive and relevant theory to explain contemporary mass consumption (Holt, 1998) and has become central to understanding contemporary consumer culture (Arnould, 2006). This paper argues that Pierre Bourdieu's contribution to understanding consumer culture can extend beyond theory, to encompass his method of conducting ethnographic research. His approach to critical ethnography: the 'Participant Objectification’ technique (Bourdieu and Wacquant, 1992 p.253) has the potential to expand the role of ethnography in the culture-based approach to brands, from the traditional textual construction embedded in macro- and mesoethnography (via the classical technique of participant observation) to a critical modeling technique, which provides dialectical understanding of culture as a co-constructed organic whole. The potential of Bourdieu's approach to ethnographic research is widely acknowledged as highly promising in organization and management research (Czarniawska, 2001; Ozbilgin and Tatli, 2005; Jarzabkowski and Whittington, 2008). 


\section{Critical Ethnography, Modeling, and Participant Objectification}

The critical approach to theory building bridges the gap between objectivism and relativism (Johnson and Duberley, 2003). Thus, ethnography is argued to be inherently critical, as it facilitates the social scientists desire (relativism) to stay in touch with the eternally changing realities (objectivism) of the social world (Thomas, 1983; Tedlock, 2000). Ethnographers build their theory of social reality from the standpoint of its social actors. They become involved in an on-going conversation with the social actors, through which their interpretations of social interactions leads to an 'improvised understanding' of the actors' construction of a social phenomenon (Denzin, 1999; Humphreys et al., 2003 p.13). Such improvised understanding enables ethnographers to link the part (their lived experiences with the social agents) to the whole (the theoretical understanding of the social world) (Baszanger and Dodier, 1997), providing a dialectical understanding which depicts how various entities are related and how social relations amongst them are renegotiated (Thomas, 1983). Moreover, since the purpose of modeling is to bridge the gap between complex practice and abstract theory by building subjective theoretical constructs that can simplify yet maintain the essence of practice (Britt, 1997, Gordon, 1999; Leeflange and Wittink, 2000), it could be argued that Bourdieu's participant objectification technique is a critical modeling technique that combines the central tenets of modeling and critical ethnography. To illustrate, Bourdieu summarized the nature of his 'participant objectification' as follows:

The ethnosociologist is a sort of organic intellectual of humankind who, as collective agent, can contribute to denaturalizing and defatalizing human existence by 
putting her competency at the service of a universalism rooted in the understanding of particularisms (in Wacquant, 2004 p.388)

Thus, according to Bourdieu and Wacquant (1992), the participant objectification technique builds models, rather than grand theories, through interrogating a concrete empirical case - seen as 'a particular case of the possible' (quoting Bachelard, 1949). The social agents' embedded unconscious of their social behavior is extracted, yielding an abstract yet coherent system of objective relations that can be empirically tested. The participant objectification technique is, therefore, argued to provide an equally-balanced co-constructed approach to modeling social behavior that bridges the gap between the researchers' role (logic of theory) and the social actors role (logic of practice) in the construction of the social world (Bourdieu and Wacquant, 1992). The application of Bourdieu's constructionist (participant objectification) technique in managerial research has been seen as an interaction amongst three logics: the logic of representation, providing the systematic analysis of data to show the structured construction of the logic of the theory drawn from active participation with the social agents in their everyday lives (the logic of practice) (Czarniawska, 2001).

The following sections will provide an illustration of the interaction amongst the three logics of participant objectification to demonstrate its critical modeling potential in branding research. The illustration is based on a study in which we systematically construct a grocery store culture (logic of representation) in order to socially model the grocery retailer as a brand (logic of theory), through daily participation with the social actors ie grocery shoppers (logic of practice). 


\subsection{The Logic of Representation}

This stage focuses on the rationale for the selection of the setting, the techniques of analysis, and presentation of data to systematically construct a grocery store culture. According to Bourdieu and Wacquant (1992), any generalizations from a participant objectification study should be built upon an empirical case that is a concrete representation of the social cosmos under study, so as to form a 'particular case of the possible' and to fulfill Bourdieu's objectification terms of '... universalism rooted in understanding of particularisms'. Since the aim of the exercise is to model the grocery retailer as a brand through understanding the meanings consumers make of their everyday encounters with grocery retailers, a typical grocery store was selected that exemplified the traditional supermarket format. The store was operated by one of the major grocery retailer brands in the UK. As an organic collective agent in the store, the researcher (one of the authors) immersed himself in the store culture for a three month period, working from $10 \mathrm{am}-7 \mathrm{pm}$ daily and adopting a covert participation style. At the end of the three month period the data was felt to be saturated. The researcher was primarily engaged in working in high customer traffic situations (eg the customer service desk, and fresh food counters), and additionally was able to embark on discussions with store employees especially those with extensive shop floor experience - about their interactions with customers. This style of engagement allowed the researcher to be naturally immersed (and hence naturally interacting with customers) in the store, and to substantiate the developed understanding of the culture held by experienced employees. 
To interrogate the case for cultural meanings, the natural setting (the store) should be conceptualized in a systematic manner (Czarniawska, 2001). Since critical inquiry is characterized as having 'ontological realism and epistemological subjectivism' (Johnson and Duberley, 2003 p.1282), consumer culture studies recommend the choice of realist ontological manifestations of culture to serve as base categories, which are then enriched and linked by the meaning systems emerging from the researcher's subjective interpretations in the field (Sherry, 1986). The four generic manifestations of culture proposed by Hofstede et al. (1990), a well established framework of culture in organizational research, were selected to guide the epistemological inquiry into store culture:

- Symbols : words, pictures, signs, or objects that carry a particular meaning within a culture;

- Heroes : live or dead, real or hypothetical, personalities who possess characteristics highly prized in the culture and thus act as or represent a model for behaviour;

- Rituals : the collective activities that are technically superficial but socially essential within a culture;

-Values : the core of culture, the unconscious and seldom discussed feelings that cannot be observed but are felt in behaviour, and thus can only be identified by analyzing the visible cues.

The consumer meanings embedded within these four cultural categories, were systematically extracted from the data by using the 'constructionist' school of grounded 
theory analysis (Strauss and Corbin 1990; Charmaz, 2006 p.9). Its systematic coding structure (see Appendix 1), as documented in Burawoy (2003), Snow et al (2003) and Charmaz (2006), compliments ethnography by providing a structured analytical process that allows the researcher to systematically construct the conceptual blocks of the proposed model from the data, and consequently validates the researcher's process (ethnographic account) of model/cultural construction. This combination of methods is encouraged in Bourdieu's participant objectification technique, as he argues that it is 'forbidden to forbid' researchers from using whatever method(s) are needed to enlighten their understanding of the social cosmos under study - as long as the methods are relevant and practical (Bourdieu and Wacquant, 1992 p.227).

Furthermore, Bourdieu and Wacquant (1992) argue that thinking in terms of an analogy is a useful tool when constructing a model, as it allows researchers to link their lived experiences (participation in the case) with their generalization (objectifying) intentions. This corresponds to the creative process of presenting ethnographic data (Van Maanen, 1988; Denzin, 1999) since ethnographers:

...don't write the discourse, it writes us through mediating our communications; it captures our imagination and through it we give expression to ourselves (Brownlie, 1997 p.277).

Thus, using the coding system of grounded theory, selective coding enabled the researchers to creatively reflect on their open and axial coding, and to present the data through a constructed metaphor. This is not just a form of discourse, like a literal metaphor, but a multilayered interactive discourse strategy that helps, through crossing 
phenomenon, to develop new theoretical perspectives (Morgan, 1980; Cornelissen, 2006).

\subsection{The Logic of Practice}

This stage focuses on the researchers' empirical investigation into customer behavior at the store. Given the methodological focus of this paper, the empirical case provided below is illustrative and restricted to a short version of the full ethnographic study. In this example, we have opted to concentrate on a representative part of the culture under study: the values emerging from the rich symbolic and ritualistic meanings of merchandise as a store object. The merchandise on offer is an integral part of any grocery store and hence becomes a window to all aspects of grocery retailing. The merchandise overlaps with store service, store format, store display, and store communications.

Using a constructed metaphor as a strategy of discourse, the findings of the study revealed the retail store culture as a tree construct. The tree is comprised of leaves (symbols) which carry the social meanings of grocery shopping that are socially processed through a network of social interactions (rituals and heroes) at the tree trunk, in the quest to attain the humanitarian essence of grocery consumption found in the tree roots (values). Using ethnographic vignettes relating to merchandise consumption in a grocery store, the following sections present the social construction of each part of the tree from a customer standpoint using the grounded theory coding system (see Appendix 2 for the procedure chart). 


\subsubsection{Tree Leaves: the merchandise as a symbol}

The properties of 'customized variety' and 'customized availability' capture the customers' quest for the concept of 'freedom of choice' which emerges as a central social meaning in the interaction between customers and merchandise in the store. By analyzing ethnographic vignettes from the grocery store setting, the following sections will explain how open and axial coding leads to the development of the concept from these properties and justifies the emergence of the 'leaves' as a selective code.

\section{Customized Variety}

In the grocery store, customers seek to customize the variety of merchandise on offer to suit their individual needs and preferences. A comment from a female shopper illustrates this: “....you used to have little Scottish produce but you have improved on that......you know when you get the local (produce) it is close and thus more fresh”. By complementing the store's efforts to source more produce locally, this customer praises the store for raising produce freshness to a level which she thought was more appropriate. In contrast, failure to offer customized variety, may reduce the attractiveness of store in the eyes of customers - another woman complained that the produce range variety was not directly suited to her family needs, so she opted to shop at a competitor's store: "the produce range is so poor no large quantities for families. I go to (competitor store) because they have a better range and quantities.”

Allowing the customization of merchandise variety to meet individual preferences provides a potent source of store competitive advantage. It pulls customers to the store: 
"You have things that no one else has, exotic things, specific fruits..."; "I come here for the fair-trade bananas,... I come here for them otherwise I'd shop at a nearby retailer, I drive here for it". As observed frequently on the customer service desk, customers regularly ask for their customized choices to be made available: "Are you going to have a vegetarian sushi?”; “Can I get cans of lemonade instead of two litre-bottles?”

\section{Customized Availability}

According to the deputy manager of the store, availability is the single most important factor from the customers' viewpoint: “Availability is the foremost. Price isn't as important; queuing is OK if availability is there”. Observations confirmed this view the main customer enquiry directed to employees on the shop floor is: "Do you have this item (that I need)?' Availability does not simply mean that the store is well stocked, but rather that the store is stocked with the products that the individual customer wants to buy: "I couldn't find the size (of butter) I need; you have got the bigger and the smaller but not what I need".

If the desired item is out of stock, this creates customer dissatisfaction: "I can not find any leaf spinach in the freezer. You used to have it, it has been four days or even a week"; "... there is no organic chicken, this is the second week" As these customer comments show, it is the frequency of customized unavailability that increases the risk of customer defection : “...unsalted butter (brand name) the small and the large pack has been out of stock for four weeks. How does not have any for this length of time? I went to another store and got it”. Incidents such as this damage store competitiveness, as the 
produce manager commented: “...customers' demand very high levels of service and availability...they (customers) say you (retailer name) do not have that, what a shame". When availability cannot be effectively communicated to customers in the store through either customer service (employees), andlor product displays problems arise. For example, the employees administrating the merchandise ordering system were subject to a grilling by one angry customer: “....for two weeks I have phoned and come over to ask about these two items. I have been told that you ordered them for this week." Customer service officer response: "they are not yet in". Customer reaction (in an angry tone), "But I expected to find them...". By breaking "promises" concerning customized availability the store risks losing customers to competitors: "I come here and everyday (frequency) they (employees) say next week for things I'm looking for... making me have to go elsewhere".

Availability is also communicated through product display. Traditionally in Britain organic products have been displayed as a separate range. When these products were relocated to be integrated within their respective product categories, this caused confusion over availability and was seen to be inconvenient: "I can not find organic tea, do you still have it?... it should be all organics in one place... now I have to travel the whole store for just an item ... in one place I can get all organics tea, coffee, whatever."

As illustrated by these vignettes, the process of open coding generated the properties of 'customized variety', and 'customized availability', with 'frequency' and 'communication' (in both service and display) evident as dimensions arising from the 
interaction between the customers and the object (merchandise) in the store. In seeking merchandise variety and availability, customers expect to find a wide and accessible range of products (freedom) tailored to their individual needs/tastes (choice). As a result, it can be argued that the concept of 'Freedom of Choice' emerges as the symbolic meaning carried to customers by the store merchandise. Additionally, the concept's dimensions (frequency and communication) indicate that this attracts customers to shop at the store (if positive) or deters customers (if negative). A sub-category, 'Strategic Charisma', could be associated with the concept of 'Freedom of Choice' via axial coding. Through having a sense of strategic enticement (charisma) and social significance (freedom of choice), the merchandise, as a symbol, can be characterized as being visible, attractive and crucial for store survival in the customer's eyes. In terms of the tree metaphor this mirrors the crucial role played by leaves in helping a tree to breath and provide an attractive shape and color. Therefore, 'tree leaves' becomes the selective code for the symbolic role of merchandise within the culture of a retail store.

\subsubsection{Tree Trunk: the rituals and heroes of merchandise}

The interactions between customers and merchandise go beyond the symbolic, to include a series of socially collective activities involving engagement with their store heroes; rendering 'heroes' in store culture as a sub-category of rituals. This engagement is encapsulated in the properties of 'social repercussions of merchandise', and 'employee sensibility', that lead to the identification of the concept of 'customer realization of selfimage' at a store. As previously, the following sections will explain how open and axial coding leads to the development of the concept and the sub-category and justifies the 
emergence of the 'trunk' as a selective code.

\section{Social Repercussions of Merchandise}

Customers tend to engage with merchandise in the negotiation of their social goals. Conversations with customers in the store, at both the fish and customer service counters, revealed the repercussions of food shopping on their relationships with themselves, their families, and friends. Buying food as a treat for themselves was a common occurrence: "I'd like a fish for a dinner, I love it baked". This phrase indicated that by cooking the fish in a particular way (baked) this customer fulfilled (love) his desires. Another customer was concerned not to spoil her meal by ensuring that the fish suited her age and lifestyle: “...no skin no bones ... I'm an old lady”. In contrast, a young man came to the service desk searching for innovation: asking for a cookbook recommendation, to "inspire” him when cooking. Customers were also nostalgic for products that evoked good memories: one customer discussed his "great time” in Spain when the swordfish reminded him of “tasty” Spanish cuisine.

Customers sought merchandise to show they cared for their loved ones: "It looks lovely the Swordfish, it's not my favourite fish but my son's, so I'll take a piece please." and to show affection: "my husband is a big man so I'd like to get a big slice, I want to impress him." Similarly, parents related to merchandise within the context of entertainment or experiences with their children: "we have been to Deep Sea World (an aquarium), so they are so excited about it" and: "She saw a programme about fish so she is so excited to see $i t^{\prime}$ 
Finally, merchandise plays a pivotal role in customer socialization with friends. For example, two customers had a complaint: first customer: "This pack (of soft drink) is outdated, we did not realise till we got home, started drinking and had some bottles." The second customer elaborated: “...we realised they had expired while we were gathering for a drink". These customers stressed that the out-of-code product had spoilt their social gathering, rather than mentioning or showing any health concerns. Another case featured a disappointed customer, who had faced an embarrassing social situation because the merchandise failed to live up to its social role: "I bought it to be a gift for someone on Sunday...I followed the instructions but it started to die... So, I couldn't take it to my friend...”

Along the axis of property, it can be seen that self-indulgence as well as affection to family and friends acts as a guide to customer behaviour towards merchandise in the store. Thus, the ideal self, family and friends play the role of the hypothetical (in the sense they are seldom present at the store) personalities who possess highly prized characteristics to which customer behaviour in the store responds. Hence, their social community members can be seen as heroes to customers in the store culture and therefore can be axially coded as the 'social motivators'.

\section{Employee Sensibility}

The social repercussions noted above were captured on the fresh food/customer service counters, and show how customers engage employees in their daily lives, expecting them to understand their social situations and to tailor (or ensure that) the merchandise fulfils their social goals. In other words, the employee was expected to show sensibility to the 
customer's desired social repercussions through the store merchandise. This sensibility is seen across two dimensions: "consulting” and "assurance”. Customer consultations varied from advice on cooking to food catering. Cooking enquires tended to be more technical: "How can I cook the Marlin? Pan frying for example" and "What is it (ice fish) like? ...and, how do we cook it?”, whilst catering enquires tended be more social in nature, as customers asked advice on serving style: "Is Avocado best in a salad or as a cold appetizer?"; on customised serving: "I'd like to buy for the three of us.... How much do I have to take?; and even on setting up a romantic situation! : "I'd like to make a nice meal for my boyfriend. What do you recommend?" Customers tended to accept employee recommendations, even when unintentionally made. For example a customer service officer arranged a bunch of flowers to out on the service desk. Many customers stopped to comment on the color coordination and then went on to buy similar flowers.

As for assurance, customers tend to make an implicit assumption that the company uses its customers for their own commercial interests. However, employees are seen as fellow humans who sympathise with customers and protect their interests. The case of a recalled brand of mineral water illustrated this point. In response to the recall advertisement, one customer asked the customer service staff (in a horrified tone) if, despite the advert stating that this was a purely precautionary measure, there really was a health problem: "I have drunk two already... Is there any danger? I am so worried." The staff member replied that it was just a standard quality check and the product was not harmful, but despite this reassurance, the customer required (with direct eye contact) further confirmation: “....that was in the paper...is it true?... no problem if I drink it?!!” 
Customers also routinely sought safety assurances about merchandise from employees during their daily shopping: "Is Lemon Sole best for babies? Does it have any bones?”; "When I cook the aubergine, can I leave the seeds in it?”; “...can this fish stay fresh till tomorrow since it is reduced to clear?"

In this category, open coding identified the 'social repercussions of merchandise', and 'employee sensibility' as the properties capturing the socially essential network (collective activities) through which customers process the merchandise in order to socially construct their image within their own social communities (themselves, family/partners and friends). Thus, the concept of 'Customer Realization of Self Image' can be said to reflect the ritualistic meanings of merchandise, since these meanings are generated through customer use of merchandise to realize (achieve) desired self-image in the eyes of their social heroes, whilst collectively engaged in the social activities of everyday life. Additionally, the employee sensibility dimensions of 'consulting' and 'assurance' suggest that employees possess highly valued personal characteristics within the store culture, which enable them to facilitate the processes of 'Customer Realization of Self Image' as well as fulfil the characteristics of a real (physically present) hero and can be, through axial coding, coded as 'catalysts'. In the case of a tree, the trunk may appear technically as just a support for the branches and leaves but more importantly it acts as the hub of the collective biological activities (including active cells) essential for a thriving tree. Thus, the 'trunk', within the tree metaphor, represents the selective code for rituals (and heroes) in a store culture. 


\subsubsection{The Tree Roots: the values of merchandise consumption}

Values are the invisible core component of a culture and are defined by its observable parts (Hofstede et al., 1990). Consequently, the open codes will be the concepts generated at the leaves and trunk. The tree leaves provide the customer with the symbolic meaning of 'Freedom of Choice', which allows them to acquire customized merchandise, to use to socially negotiate self-image with the motivators (heroes) in their own social community, which is captured in the trunk by the ritualistic meaning of 'Realization of Self-image'. Such acquisition of selected materialistic objects (merchandise) through which they can negotiate their own self-worth within their social community is the customer quest for a form of respect identified by the Stanford Encyclopedia of Philosophy (2007) as the concept of 'Self Esteem'. Such abstract ethical values (e.g. respect, trust, etc.) are the spiritual bases of the human quest to discover selfmeaning in life -- particularly within the increasingly secular societies (Somerville, 2006). Consequently, values can selectively be coded as the 'roots' of the tree.

Using axial coding, it can be argued that the tree metaphor (from roots to trunk to leaves) mirrors the phases comprising a customer's social self concept (Mead, 1934). According to Mead, the social self has two phases, 'I' and 'ME'. The latent raw 'I' (captured in the "roots" concept of 'Self Esteem') takes its meaning through socializing with "significant others” to form the 'ME', a process which Mead describes: “...we cannot realize ourselves except in so far as we recognize the other in his relationship to us. It is as he takes the attitude of the other that the individual is able to realize himself as a self" p.194 (captured by the "trunk" concept of 'Realization of Self Image'). Mead then argues that 
the social negotiations of 'ME', bring the ' $\mathrm{I}$ ' to the fore in the form of a novel/creative image, which Mittal (2006) identified as a third phase, "MINE". This is the acquisition of an object to represent the social self (ME) and is thus known as the 'extended self' (Belk, 1988), and is captured by the leaves concept of 'Freedom of Choice'. The concept of 'Social Self' (I) therefore becomes a sub-category within the values category with (Me) and (Mine) as its properties. Figure 1 summarizes the construction of the tree metaphor from the meanings generated from the cultural categories of a retail store.

\subsection{The Logic of Theory}

This stage focuses on the dialectical construction of the model from the data through linking the part to the whole. Casting an eye on the three parts of the Tree as a constructed metaphor, first, the 'strategic charisma' of the leaves relates to the strategic communication role encapsulated in the brand equity and brand personality approach, which can be explored through micro-ethnographic studies. Second, the trunk's central role as a hub of socialization for realizing self-image/meaning, illustrates the potential of meso-ethnography projects to capture customer's formation (production) of brand meanings, as postulated by the sociological approach to branding, whilst producing differentiation in their social world amongst their social heroes (significant others), which Bourdieu (1979) termed the 'habitus' in his cultural capital theory. The central role of the dynamic habitus to retail branding can best be demonstrated by Miller's (1998) theory of shopping that resonates with the nature of rituals (the trunk) in this case study. Miller argues that, from a standpoint of the primary shopper in the household, women negotiate their familial social relationships through food shopping to continuously (re)form their 
identities (differentiation) as the family's prime love-giver. This case-study adds to Miller's theory, in that identity (differentiation) creation can also be facilitated by the sensibility of the store's local heroes - the catalyst employees. Miller's view therefore suggests that the habitus role in retail branding, like the trunk's natural role in a tree, is central as its ceaseless collective activities not only form social relationships but also bond the strategic role of the merchandise/object (leaves) to the ethical role of the generic social values/love (root). Thus, the roots reflect the anthropological view of brands, and the potential of macro-ethnographic studies in capturing the ethical foundations of human spirituality that a brand - via its persona - can tap into, to form a spiritual bond with consumers (Sherry, 2008).

As the case study suggests, since the basic values of a culture have the ability to align the components of the social self concept, the tree as an organic whole (with the anchoring roots aligning the biologically active bonding role of the trunk and the strategic role of the leaves) can provide a dialectical understanding of the consumption and production of meanings by customers in a retail setting. These are embedded within a grocery brand culture: having an anthropological foundation (the basic human values - I); are sociologically formulated via rituals (habitus $-m e$ ) to produce social differentiation and are psychologically communicated via symbols (the socio-economic meaning - Mine). Thus, it could be concluded that the tree as an organic whole is a critical model, which from the consumer's standpoint draws out the various cultural 'meaning' phases involved in building a grocery retailer brand, as well as illustrating the contribution of various 
types of market-oriented ethnography to building each phase in a dialectic construct (see Table 1).

Table (1): Tree as a dialectic model of the grocery retailer as a brand/cultural process

\begin{tabular}{|c|c|c|c|c|}
\hline $\begin{array}{l}\text { Abstract } \\
\text { Culture } \\
\text { Categories }\end{array}$ & $\begin{array}{l}\text { Tree Metaphor } \\
\text { Concepts in } \\
\text { grocery retailing }\end{array}$ & $\begin{array}{l}\text { Customer } \\
\text { Social } \\
\text { Self } \\
\text { Concept }\end{array}$ & $\begin{array}{l}\text { Modes of } \\
\text { Ethnographic } \\
\text { Research in } \\
\text { Branding }\end{array}$ & $\begin{array}{c}\text { Tree as a Critical } \\
\text { Model of Branding } \\
\text { as a } \\
\text { Cultural process }\end{array}$ \\
\hline Symbols & $\begin{array}{l}\text { Leaves } \\
\text { 'carriers of the } \\
\text { strategically } \\
\text { charismatic } \\
\text { 'freedom of } \\
\text { choice' }\end{array}$ & Mine & $\begin{array}{l}\text { Micro- } \\
\text { ethnography }\end{array}$ & $\begin{array}{l}\text { Strategic } \\
\text { Communication } \\
\text { Stage } \\
\text { managerial equity } \\
\text { and psychological } \\
\text { view of brands }\end{array}$ \\
\hline $\begin{array}{c}\text { Rituals \& } \\
\text { Heroes }\end{array}$ & $\begin{array}{c}\text { Trunk } \\
\text { 'the socialization } \\
\text { hub of } \\
\text { customers' } \\
\text { realization of } \\
\text { self-image' }\end{array}$ & $\mathrm{Me}$ & $\begin{array}{c}\text { Meso- } \\
\text { ethnography }\end{array}$ & $\begin{array}{c}\text { Formulation } \\
\text { Stage } \\
\text { sociological view } \\
\text { of brands }\end{array}$ \\
\hline Values & $\begin{array}{c}\text { Roots } \\
\text { 'the anchoring } \\
\text { value of respect/ } \\
\text { self-esteem' }\end{array}$ & $\overline{I I}$ & $\begin{array}{l}\text { Macro- } \\
\text { ethnography }\end{array}$ & $\begin{array}{c}\text { Foundation } \\
\text { Stage } \\
\text { anthropological } \\
\text { view of brands }\end{array}$ \\
\hline
\end{tabular}

\section{Conclusion: the potential of modeling brands critically}

Critical modelling occurs through the researchers' ethnographic involvement in a social phenomenon as a collective agent to model the social behaviour of the social actors. This 
is a process encapsulated by Pierre Bourdieu's participant objectification technique. This technique embodies the potential to extend the role of ethnography in brand management from cultural textual construction (participant observation) to dialectal construction (participant objectification) and therefore to form empirically grounded and multi-faceted models. The potential application of these models in branding research has been demonstrated in this study of a grocery retailer as a brand. The outcome was a dialectic understanding of the brand as a culture that is not just represented pictographically as a tree but, more importantly, acts as an organic entity that is capable of modeling the branding process as a cultural whole - a process that is composed of a complex set of different, yet interdependent, social and technical systems of meaning, functioning in a coherent and complementary manner.

To illustrate, the different yet interdependent roles of the trees constituent parts (roots, trunk, leaves) simply, yet aptly, illustrate how an intricate living system coherently and naturally works to sustain growth, through synchronizing the flow of relationships and interconnections amongst the anchoring roots, active trunk and strategic leaves. Hence, the tree as an organic model could provide brand managers and researchers with a naturally integrated framework capable of sustaining the growth of the brand as a cultural process. As an organic whole, the tree helps to fuse the various modes of ethnographic research into a practice-based understanding of the customer's construction of meaning within a brand culture producing a matrix of dialectical (critical) cultural understanding. This in turn synchronizes the flow of relationships and interconnections amongst the roles of its different yet interdependent meaning-constituting levels: the anthropological 
foundation; the sociological formulation; and psycho/strategic communication (see Table 1). The tree model therefore can help brand managers to guard against the disconnect amongst the brand's intricate multi-level - cultural, social and strategic- meaning structure. This is achieved by providing a dynamic framework for understanding brands as self-reflective organic entities that, in turn, render managing and researching brands a circular process. This circular understanding resonates with the practice-based approach to organizational management and research (Gherardi, 2001; Ozbilgin and Tatli, 2005; Jarzabkowski and Whittington, 2008). The dynamic value of such as approach is articulated by Gherardi (2001) as:

“(organizational) learning cannot be compartmentalized into levels and divided up among different scientific disciplines ....these may be heuristically useful distinctions as long as we (managers/scholars) bear in mind that (practical) knowledge circulates among and unites these various levels and that any distinction into levels is purely arbitrary" (p.132).

Since the tree models the dynamics of retail branding (see Table 1), the value of critical ethnography modeling could be to provide theory with a 'pragmatic validity' that assimilates theory and practice into a single entity of self-reflective knowledge. This makes it capable of remedying the accusation that theory is detached from the complexity of the real world (Gherardi, 2001; Worren et al., 2002 p.1231; Ozbilgin and Tatli, 2005; Jarzabkowski and Whittington, 2008). This has often been a criticism of traditional marketing models (Ehernberg et al., 2000; Roberts, 2000). Hence ethnographic modeling can potentially provide an ethical (Arvidsson, 2008) and a sustainable (Sherry, 2008) approach to branding as an open process. Besides, critical ethnography modeling in branding demonstrates the important role of the metaphor in helping marketers to make sense of the complex concept of a brand (Davies and Chun, 2003)- as typified by the tree. 
The tree's organic nature has changed the role of the metaphor from being simply a potent pictorial illustration (Gordon, 1999) to release its full potential as a strategically constructed method of analysis (Cornelissen, 2003; 2006) capable of developing dialectical conceptualizations of brands.

Finally, despite the promising prospects for critical ethnographic modeling in branding as exemplified by the tree - its potential limitations could be bound up in the debate over its validity and reliability, from the standpoint of the dominant positivist approach. However, since ethnography is conducted in natural settings, the data generated is argued to be highly valid (Arnould and Wallendorf, 1994; Moisander and Valtonen, 2006). Additionally, the ethnographer's reflective accounts of these settings are also validated, as it is scientifically imperative to include in the objectified/model the inherent viewpoint of the researcher who objectifies it (Bourdieu and Wacquant, 1992), a view welldocumented as central to critical research in marketing and management (Weick, 1999; Czarniawska, 2001; Brownlie, 2006; Saren et al., 2007).

As for reliability, Calder et al. (1982 p.243) vehemently question its relevance in theorybuilding research, they argued it is 'practically infeasible and logically impossible' and thus can only hinder theoretical development. This view is widely endorsed in critical management and marketing research (Czarniawska, 2001; Burton, 2005; Brownlie, 2006). Nonetheless, reliability is argued to be vital for the predictive power of the positivist managerial models (Leeflang and Wittink, 2000). Critical management opposes such a stance, given the volatile nature of social phenomena and the models' inherently 
subjective nature, arguing that reliability can only be seen in the consistency and discipline of the process of construction leading to model as an (not the) objectification of a phenomenon (Weick, 1999; Czarniawska, 2001). Predictive power of sociallyconstructed models is possible via regular re-visits to the site of practice to update records of the social actors' construction of the phenomenon (Burawoy, 2003). Based on such a continuous record, predictions of actors' behavior could be made (Burawoy, 2003; Wacquant, 2004). As such, the potential of modeling brands critically is summed up in its inherent organic attitude to the branding process, which therefore advocates a shift in the orientation to brand management from the traditional industrial approach - that is characterized by exerting control on a manufactured process - to an natural approach that is characterized by continuous nourishing and nurturing of a naturally occurring (social) process. 


\section{$\underline{\text { References }}$}

Aaker, D. (1996) Building Strong Brands, The Free Press, New York.

Arnould, E. (2006), "Towards a culturally informed resource-based theory of the customer”, European Advances in Consumer Research, Vol.7, pp. 6-9.

Arnould, E. and Price, L. L. (2006), “Market-Oriented ethnography revisited”, Journal of Advertising Research, Vol. September, pp. 251-62.

Arnould, E. and Wallendorf, M. (1994), "Market-Oriented ethnography: interpretation building and marketing strategy formulation”, Journal of Marketing Research,Vol. XXXI (November), pp.484-504.

Arvidsson, A. (2005) “Brands: a critical perspective”, Journal of Consumer Culture, Vol. 5 No.2, pp. 235-58.

Arvidsson, A. (2008) “The ethical economy of customer coproduction", Journal of Macromarketing, Vol. 28 No.4, pp. 326-38.

Baszanger, I. and Dodier, N. (1997), "Ethnography: relating the part to the whole”, in Silverman, D. (Ed.), Qualitative Research: Theory, Method, and Practice, Sage Publications, Thousand Oaks, California, PP.8-23.

Belk, R. (1988), "Possessions and the extended self”, Journal of Consumer Research, Vol.15, pp.139-68.

Bourdieu, P. (1979), Distinction: A Social Critique of the Judgment of Taste, Routledge and Kegan Paul, London.

Bourdieu, P. and Wacquant, J.D. (1992), An Invitation to Reflexive Sociology, The University of Chicago Press, Chicago.

Britt, D.W. (1997) A Conceptual Introduction to Modeling: Qualitative and Quantitative Perspectives, Lawrence Erlbaum Associates, Hillsdale, NJ.

Brown, S. (1993), “Postmodern marketing?” European Journal of Marketing, Vol. 27 No.4, pp.19-34.

Brownlie, D. (1997), "Beyond ethnography: towards writerly accounts of organizing in marketing”, European Journal of Marketing, Vol. 31 No.3/4, pp.264-84.

Brownlie, D. (2006) "Emancipation, epiphany and resistance: on the underimagined and overdetermined in critical marketing”, Journal of Marketing Management, Vol. 22, pp.505-28. 
Burawoy, M. (2003), "Revisits: an outline of a theory of reflexive ethnography", American Sociological Review, Vol. 68 No.5, pp.645-79.

Burton, D. (2002), "Towards a critical multicultural marketing theory", Marketing Theory, Vol. 2 No.2, pp.207-36.

Burton, D. (2005), “Marketing Theory Matters”, British Journal of Management 16(1):518.

Calder, B.J., Phillips, L.W. and Tybout, A.M. (1982), “The concept of external validity”, Journal of Consumer Research, Vol. 9(December), pp.240-44.

Calonius, H. (2006), "Contemporary research in marketing: a market behaviour framework”, Marketing Theory, Vol. 6 No.4, pp.419-28.

Charmaz, K. (2006), Constructing Grounded Theory, Sage Publications, London.

Coupland, J.C. (2005), "Invisible brands: An ethnography of households and the brands in their kitchen pantries”, Journal of Consumer Research Vol. 32(June), pp.106-18.

Cornelissen, J. P. (2003), "Metaphor as method in the domain of marketing”, Psychology \&Marketing, Vol. 20 No.3, pp.209-25.

Cornelissen, J. P. (2006), "Making sense of theory construction: metaphor and disciplined imagination”, Organization Studies, Vol. 27 No.11, pp.1579-97.

Czarniawska, B. (2001), "Is it possible to be a constructionist consultant?" Management Learning, Vol.32 No.2, pp.253-66.

Davies, G. and Chun, R. (2003), "The use of metaphor in the exploration of the Brand concept”, Journal of Marketing Management, Vol.19, pp.45-71.

de Chernatony, L. and Riley, F.D. (1998), "Modeling the components of the brand" European Journal of Marketing, Vol.32 No.11/12, pp.1074-90.

Dube, J., Sudhir, K. C., Andrew, C., Gregory S., Dranganska, M., Fox, J.T., Hartmann, W., Hitsch, G. J., Viard, V. B., Villas-Boas, M. and Vilcassim, N. (2005), "Recent advances in structural econometric modeling: dynamics, product positioning and entry", Marketing Letters, Vol.16 No.3/4, pp.209-224.

Dyson, D., Farr, A. and Hollis, S. (1996), "Understanding, measuring, and using Brand equity”, Journal of Advertising Research, Vol. November/ December, pp.9-21. 
Denzin, N. K. (1999), "Interpretive ethnography for the next century", Journal of Contemporary Ethnography, Vol. 28 No.5, pp.510-19.

Ehernberg, A. S.C., Barnard, N. R. and Sharp, B. (2000), “Decision models or descriptive models?”, International Journal of Research in Marketing, Vol.17 No.2/3, pp.147-58.

Elliott, R. and Jankel-Elliott, N. (2003), "Using ethnography in strategic consumer research”, Qualitative Market Research: An International Journal, Vol.6 No.4, pp.21523.

Gherardi, S. (2001), "From organizational learning to practice-based knowing”, Human Relations, Vol. 54 No.1, pp.131-139.

Gordon, W. (1999) Goodthinking: A guide to Qualitative Research, Admap, Oxfordshire, $\mathrm{UK}$

Gummesson, E. (2000) Qualitative Methods in Management Research, Sage Publications, London.

Hofstede, G., Neuijen, B. and Ohayv, D.D. (1990) "Measuring organizational cultures: a qualitative and quantitative study across twenty cases”, Administrative Science Quarterly, Vol.36 No.2, pp. 286-316.

Holt, D.B. (1998), “Does cultural capital structure American consumption”, Journal of Consumer Research, Vol. 25(June), pp.1-25.

Holt, D. (2002), "Why do brands cause trouble? A dialectical theory of consumer culture and branding”, Journal of Consumer Research, Vol. 29(June), pp.70-90.

Holt, D. (2004) How Brands Become Icons: The Principles of Cultural Branding, Harvard Business School Press, Boston, Mass.

Humpherys, M., Brown, A.D. and Hatch, M. J. (2003), “Is ethnography jazz?” Organization, Vol.10, No.1, pp.5-31.

Jarzabkowski, P. and Whittington, R. (2008), “A strategy-as-practice approach to strategy research and education”, Journal of Management Inquiry, Vol.17 No.7, pp.282-286.

Johnson, P. and Duberley, J. (2003) "Reflexivity in management research", Journal of Management Studies, Vol. 40 No.5, pp. 1279-1303.

Kapferer, J. (1997) Strategic Brand Management. Kogan Page, London.

Keller, K. L. (2008) Strategic Brand Management. Prentice Hall, Upper Saddle River,NJ. 
Kent, R. (1996), "The protestant ethic and the spirit of marketing: visions of the end" in Brown, S., Bell, J. and Carson, D. (Ed.), Marketing Apocalypse: Eschatology, Escapology, and the Illusion of the End, Routledge, London, pp.133-44.

Kincheloe, J.L. and McLaren, P. (2000) "Rethinking critical theory and qualitative research” in Denzin, N.K. and Lincoln, Y.S. (Ed.), Handbook of Qualitative Research, Sage Publications, Thousand Oaks, California, pp. 279-313.

Klein, N. (2000) No Logo, Vintage Canada, Toronto.

Leeflange, P.S.H. and Wittink, D.R. (2000), "Building models for marketing decisions: past, present and future”, International Journal of Research in Marketing, Vol.17 No.2/3, pp.105-26.

Leigh, T. W., Peters, C. and Shelton, J. (2006), “The consumer quest for authenticity: the multiplicity of meanings within the MG subculture of consumption", Journal of the Academy of Marketing Science, Vol.34 No.4, pp.481-93.

Malhotra, N. K. Peterson, M. and Kleiser, S. B. (1999), "Marketing Research: A State-of -the-Art Review and Directions for the Twenty-First Century", Journal of the Academy of Marketing Science, Vol. 27 No.2, pp.160-83.

McCracken, G. (1993) "The value of the brand: an anthropological perspective", in Aaker, D.A. and Biel, A. L. (Ed.), Brand Equity and Advertising, Lawrence Erlbaum Associations, Hillsdale, NJ, pp.125-39.

Mead, G. H. (1934) “The self”, in Morris, C. (Ed.), Mind, Self, and Society: from the Standpoint of a Social Behaviorist, The University of Chicago Press, Chicago, pp. 135226.

Miller, D. (1998), A Theory of Shopping, Cornell University Press: New York.

Moisio, R., Arnould, E. and Price, L. L. (2004), "Between mothers and markets: constructing family identity through homemade food", Journal of Consumer Culture, Vol.4 No.3, pp.361-84.

Morgan, G. (1980), "Paradigms, metaphors, and puzzle-solving in organisation theory”, Administrative Science Quarterly, Vol.25 No.4, pp.605-20.

Moorthy, S. K. (1993), “Theoretical modeling in marketing”, Journal of Marketing, Vol. 57 (April), pp. 92-106.

Mintzberg, H. (1979), “An emerging strategy of "Direct” research", Administrative Science Quarterly, Vol. 24(December), pp.582-89. 
Mittal, B. (2006), “I, me, and mine-How products become consumers extended selves”, Journal of Consumer Behavior, Vol.5 (Nov.-Dec.), pp.550-62.

Moisander, J. and Valtonen, A. (2006) Qualitative Marketing Research: a Cultural Approach. Sage Publications, London.

Muniz, A. Jr. and O’Guinn, T. (2001), "Brand community”, Journal of Consumer Research, Vol. 27(March), pp.412-32.

Ozbilgin, M. and Tatli, A. (2005), “Undertanding Bourdieu's contribution to organization and management studies”, Academy of Management Review, Vol.30 No.4, pp.855-877

Pitt, L., Watson, R., Berthon, P., Wynn, D. and Zinkhan, G. (2006), “The penguin’s window: corporate brands from an Open-Source perspective', Journal of the Academy of Marketing Science, Vol.34 No.2, pp.115-27.

Reed, A. (2002) "Social identity as a useful perspective for self-concept-based consumer research”, Psychology \& Marketing, Vol.19 No.3, pp.235-66.

Roberts, J.H. (2000) “The intersection of modeling potential and practice”, International Journal of Research in Marketing, Vol. 17 No.2/3, pp.127-34.

Saren, M., Maclaran, P., Goulding, C., Elliott, R., Sankar, A. and Catterall, M. (2007) "Introduction: Defining the field of critical marketing" in Saren, M., Maclaran, P., Goulding, C., Elliott, R., Sankar, A. and Catterall, M. (ed.) Critical Marketing: Defining the field, Oxford: Butterworth-Heinemann.

Sherry, J. F. (1986) “The cultural perspective in consumer research”, Advances in Consumer research, Vol.13, pp.573-575.

Sherry, J. F. (2008) "The ethnographer's apprentice: trying consumer culture from the outside in”, Journal of Business Ethics 80:85-95.

Shouten, J.W. and McAlexander, J. H. (1995), "Sub-Cultures of Consumption: An Ethnography of the New Bikers”, Journal of Consumer Research, Vol.22 (June), pp.43-61.

Snow, D.A., Morrill, C. and Anderson, L. (2003), "Elaborating Analytic Ethnography: Linking Fieldwork and Theory”, Ethnography, Vol.4 No.2, pp.181-200.

Somerville, M. (2006) The Ethical Imagination: Journeys of the Human Spirit, House of Anansi Press, Toronto.

Stanford Encyclopedia of Philosophy (2007) 'Respect' [on-line] http://plato.stanford.edu/enties/respect/ (Access 18/6/2007). 
Strauss, A. and Corbin, J. (1990) Basics of Qualitative Research, Sage Publications, Thousand Oaks, California.

Tedlock, B. (2000) 'Ethnography and Ethnographic Representation, in Denzin, N. K. and Lincoln, Y.S. (Ed.), Handbook of Qualitative Research, Sage Publications, Thousand Oaks, California, pp. 455-86.

Thomas, J. (1983) "Towards Critical Ethnography: A Reexamination of the Chicago Legacy”, Journal of Contemporary Ethnography, Vol.11 No.4, pp.477-90.

Van Maanen, J. (1988), Tales of the Filed: On Writing Ethnography, The University of Chicago Press, Chicago and London.

Wacquant, L. (2004), "Following Pierre Bourdieu into the filed”, Ethnography, Vol.5 No.4, pp.387-414.

Weick, K. E. (1999) “Theory construction as disciplined reflexivity: tradeoffs in the 90s”, Academy of Management Review, Vol. 24 No.4, pp. 797-805.

Worren, N., Moore, K. and Elliot, R. (2002), "When Theories Become Tools: toward a Framework for Pragmatic Validity”, Human Relations, Vol.55 No.10, pp.1227-50. 